\title{
A DANÇA E O XAMANISMO: OS PROCESSOS EDUCATIVOS MITO-RITUALÍSTICO DO COTIDIANO GUARANI
}

\author{
ANA LUISA TEIXEIRA DE MENEZES ${ }^{1}$
}

UNISC

\begin{abstract}
RESUMO: Este artigo busca desenvolver uma reflexão sobre a dança Guarani e o xamanismo, enfocando os aspectos mitológicos e ritualísticos dentro de um processo educativo e cotidiano. Na dança, a consciência da coletividade é vivenciada através do pensamento e do sentimento. A vivência provocada pelo coletivo na dança pode ser traduzida como nhandereté, corpo de todos, como divina e produtora de alegria. Nas intempéries do cotidiano, o Guarani produz beleza e alegria, porque são a expressão de suas identidades divinas. Através de conversas e depoimentos com os jovens Guarani buscou-se enfocar as elaborações feitas por estes, do conhecimento mitológico e da vivência cotidiana. O rito cumpre uma função vivificadora do mito e estes dois aspectos são percebidos como entrelaçados à dança e à Opy. Todos estes aspectos são vividos pelos jovens e adultos de uma forma muito inquietante que os levam à um movimento permanente de indagações, buscas e redefinições. Dentro desse processo, a Opy, o Karaí e a dança são destacadas como fundantes da cultura Guarani e servem como pontos de estabilização dentro de um cotidiano tão dinâmico. A dança, enquanto rito, transporta os Guarani a um tempo de reconhecimento de suas identidades, de um ritmo de vida. O rito Guarani está ligado a uma estrutura profunda de organização coletiva emocional, dentro de uma função vital, de elevação espiritual e uma integração ao seu sistema de pertença. Para os Guarani, Nhanderú ensinou a dança e mandou dançar a dança. Esta surge de uma percepção mitológica e o seu surgimento confunde-se com a própria existência Guarani. A espiritualidade nasce de uma relação vital, de movimento. A educação xamânica é apreendida pelos sentidos. A noção principal de conhecimento é o Arandurekó, conhecimento que se aprende ao longo da vida, num tempo-ritmo próprio. A dança-rito possibilita a conexão entre corpo e espírito, proporcionando uma escuta sensivel dos gestos, das doenças, dos comportamentos como espaços reflexivos de aprendizagem. Pôr-se em movimento, no contexto ritualístico xamânico Guarani, estimula o transe, um estado alterado de percepção, como um fluir na mente, que permite que as imagens e os sentidos aflorem, estimulando um processo de aprendizagem vivencial e reflexivo. A educação de cada Guarani é permitir e favorecer esta conexão processual. Para isso, é exigido um esforço de toda uma vida, uma formação e também uma perseverança que muitos jovens almejam ter.
\end{abstract}

PALAVRAS CHAVE: Dança Guarani; Mito; Rito; Xamanismo; Educação.

ABSTRACT: This article aims at developing a reflection over the Guarani dance and shamanism, highlighting the mythological and ritualistic aspects within an ordinary and educative process. In the dance, a conscious of collectivity is experienced through thought and feeling. The experience provoked by the collectivity in the dance can be translated as nhaderetê, body of all, divine and joy producer. In the daily bleakness, the Guarani produce beauty and joy, because these are the expression of their divine entities. Throughout conversation and

\footnotetext{
${ }^{1}$ Professora de Psicologia na Universidade de Santa Cruz do Sul. Doutora em Educação pela UFRGS. Email: luisa@unisc.br.
}

Espaço Ameríndio, Porto Alegre, v. 2, n. 1, p. 111-128, jan./jun. 2008. 
ANA LUISA TEIXEIRA DE MENEZES - A dança e o xamanismo ...

testimonies of young Guarani, we sought to highlight their elaborations of the mythological knowledge and daily living. The rite has a living function of the myth and these two aspects are perceived as interweaved to the dance and to the Opy. All these aspects are lived by the young and adults in a very disturbing way that leads them to a permanent movement of questioning, search and redefinition. In this process, the Opy, the Karai and the dance are highlighted as basis of the Guarani culture and serve as stabilization points within a very dynamic daily. The dance, as rite, transports the Guarani to a time when they acknowledge their identities, in a life rhythm. The Guarani rite is linked to a deep structure of the emotional collective organization, in a vital function, of spiritual elevation and integration to their belonging system. To the Guarani, Nhanderu taught the dance and enforced them to dance. This becomes from a mythological perception and its appearance is confounded with the own Guarani existence. The spirituality appears from a vital relation of movement. The shamanistic education is learned by the senses. The main knowledge notion is the Arandureko, knowledge that is learned throughout life, in proper time and rhythm. The dance-rhythm enables the connection between body and spirit, proportioning a sensible hearing of gestures, diseases, and behavior as reflexive learning spaces. By putting themselves in movement, in the ritualistic Guarani shamanistic context, it stimulates the trance, an altered state of perception, as a mind flow, that permits that the images and senses to flourish, stimulating a living and reflexive learning. The education of each Guarani is to permit and to favor this process connection. Therefore, it demands a lifelong effort, a formation and also a perseverance that many youngsters seek to have.

KEY WORDS: Guarani dance; Myth; Rite; Shamanism; Education.

A dança e os mitos estão profundamente imbricados dentro de um universo xamânico Guarani. Ao refletir sobre os mitos, a dança e o xamanismo Guarani, busca-se compreender como estes aspectos, considerados centrais nesta cultura, interagem enquanto um processo educativo, ritualístico e cotidiano.

Para os Guarani, Nhanderú ${ }^{2}$ dança. A posição vertical na dança, conforme descreve Alberto, professor Guarani, é uma aspiração Guarani, como uma possibilidade de desdobramento de Nhamandü de desdobrar sua própria natureza divina (CLASTRES, 1990). A idéia de desdobramento está presente no mito de criação descrito pelo autor.

No início é o deus. Ele aparece e dilata-se, desdobra-se como uma flor que se abre à luz do sol. Mas Nhamandú é para si mesmo o próprio sol, é ao mesmo tempo sol e flor [...]. Mãos cujos dedos são ramagens floridas, cabeça como o cimo de uma árvore em plena floração. Nhamandú é a vida (CLASTRES, 1990, p. 23).

Além da mitologia do aparecimento de Nhamandú, o autor retrata

\footnotetext{
${ }^{2}$ Divindade religiosa Guarani

${ }^{3}$ Divindade religiosa Guarani representada como o Sol
}

Espaço Ameríndio, Porto Alegre, v. 2, n. 1, p. 111-128, jan./jun. 2008. 
o mito do dilúvio, a aventura dos gêmeos e o mito da origem do fogo como estruturantes da mitologia Guarani. No mito do dilúvio, na versão de Nimuendajú (apud CLASTRES, 1990), o grande pai avisou a Guyraypoty para que eles dançassem, pois um grande mal iria se abater sobre a Terra. E dançaram durante três anos, até que a Terra começasse a ser destruída. No mito dos gêmeos, Nandevurussu, quando descobre que os gêmeos gestados por sua mulher não eram dele, mas de Nhanderú Mbaekuaa, sonhou que devia ir embora dançando e, dançando, levantou-se. Já em uma das versões do mito da origem do fogo, os corvos donos do fogo tinham o hábito de dançar e íam se transformando em Tupã. Cito essas estórias mitológicas para destacar a presença das danças na construção do pensamento Guarani, o que justifica em parte a conservação das danças na educação deste povo. $O$ enraizamento da dança no mito Guarani da criação do mundo, conforme afirma Rodriguez (1999), pode também dever-se ao fato de ser uma cosmologia que se produz em movimento. $\mathrm{O}$ autor cita o bastão ritual de Nhanderú, o popenguá e o pethenguá no qual, através do fumo, evocase a divindade Jakairá e o movimento do sol, na presentificação de Nhamandú. Este movimento, enquanto modo de ser, vai sendo redefinido no diálogo entre realidade e mito. Cadogán (1959) cita uma das versões dos mitos Guarani de um cataclisma que ameaçava destruir o mundo através do fogo, no qual, Nhanderú ru kutíu, percebendo que o mundo ía ser destruído, cantou e dançou e transformou-se num pássaro Kutíu, evitando a destruição. Outro mito, no qual a dança possui um papel central, é o descrito por Nimuendaju apud Cadogán (1959): Charypiré, que conta como sendo uma mulher, salvou a si e a seu filho, cantando e tocando o takuapú. Em troca desta devoção, estes foram salvos por uma palmeira pindó, considerada sagrada, e alcançaram o aguyjé, a perfeição. Conforme a mitologia Guarani, no tempo do dilúvio, as pessoas foram chamadas a dançar ao invés de trabalhar (CLASTRES, 1990).

Cadogán (1959) mostra como os Guarani Chiripá no Paraguai interpretam a dança ritual dentro do contexto em que vivem. Cita um líder religioso que indaga: "Como podemos cantar?", referindo-se ao fato de que, quando canta, sua mulher indaga como ele pode cantar se

\footnotetext{
${ }^{4}$ Bastão usado na dança como instrumento sagrado. Feito de cedro.

${ }^{5}$ Cachimbo utilizado nos rituais como uma forma de comunicação divina. Os Guarani acreditam que a fumaça por ele gerada possui uma função de purificação.
}

Espaço Ameríndio, Porto Alegre, v. 2, n. 1, p. 111-128, jan./jun. 2008. 
não há comida, nem óleo, nem sal. Comenta que, com raiva, não pode cantar. Este sentimento expressa uma dualidade vivida pelos adultos, entre os ensinamentos da infância e a realidade de agora, entre a aldeia e a cidade, espaços que se constroem numa dicotomia entre o bem e o mal. Alberto Ortega, em leituras conjuntas sobre Cadogán, indagou-me: "se não tenho o real, como vou dançar? Tem que ter sentimento puro para dançar". O sentimento puro é vivido dentro de uma cosmologia. Bergamaschi (2005) em seus estudos com os Guarani, refere-se a cosmologia como um complexo cultural e como práticas que vão dando sentido ao cotidiano, da Tekoa ${ }^{6}$.

Langdon (1996) propõe pensar o xamanismo como uma visão cosmológica, como uma instituição, que tenta compreender a organização da vida cotidiana, que envolve os mitos, os ritos, a noção de poder, os estados de consciência, o lúdico e a estética. Sem negar a força do xamã e seu papel religioso, conforme desenvolveu Eliade (1998), Langdon (1996) nos amplia a percepção sobre o xamanismo. Quanto mais o xamã está enraizado na comunidade, ou seja, é vinculado com esta e preocupa-se com os moradores, investindo suas forças na construção da mesma, mais exerce seu poder coletivamente, ou melhor, o poder torna-se coletivo, porque a comunidade usufrui de seus efeitos. Desta forma, o xamanismo é vivenciado e torna-se um sistema: saberes compartilhados e construídos coletivamente. O xamanismo revigora-se no compartilhar e, desta forma, é vivido como um sistema educacional.

Bruneli (1996), em seus estudos sobre o xamanismo com os Zoró e com os povos Tupi-Mondé, no Brasil, constata que, apesar de não serem mais encontrados xamãs trabalhando ativa e orgulhosamente nas aldeias, o xamanismo não desapareceu para sempre, pois ainda persiste a relação ontológica entre o mundo visível e invisível, entre os seres e os poderes da natureza. Nesta visão, pode-se falar que não há xamãs, mas há xamanismo. Segundo o autor, há uma reatualização na estrutura cosmólogica no universo Zoró que permitirá um dia, o ressurgimento de novos xamãs, ou não, caso esta reestruturação esteja ligada à afirmação de uma nova identidade étnica. $O$ autor supõe que assumir ou não o xamanismo está diretamente vinculado ao tipo de identidade étnica que irá ser redefinida em cada contexto.

\footnotetext{
${ }^{6}$ Aldeia, ambiente onde o Guarani estabelece seu modo de vida.
} 
Entre os Mbyá-Guarani do Rio Grande do Sul, o termo xamanismo não é apropriado por eles em sua linguagem cotidiana. Certa vez, falei sobre xamanismo com um Guarani, Alberto Ortega, e este disse-me que xamanismo é uma religião. Outra vez, uma liderança não quis conversar sobre o tema, alegando que isso era assunto deles?

Montardo (2002) encontra na cultura Guarani Kaiová, no Mato Grosso do Sul, aspectos de uma educação xamânica, através da dança e do canto. Esta autora trabalha o xamanismo na perspectiva de Langdon (1996), como um sistema que envolve a política, a estética e a cultura. Susnik apud Montardo (2002), reconhece nos Guarani o ritual de transe, mas alega que este foi substituído pela reza. Na visão de Montardo, nos rituais musicais, nos cantos e nas danças há uma alteração ou ampliação do estado de consciência. Cicarone (2001), em seu trabalho com os Mbyá Guarani do Espírito Santo, explora o xamanismo como caminhos de desordem e de deslocamento próprios dos Guarani. Segundo a autora, a líder espiritual sempre lembrava em sua fala que o Guarani não pode deixar de caminhar, pois esta é uma condição para que exista vida na Terra. Isto revela bem a contradição vivida entre não ter mais espaço de vida, mata, natureza, animais e a desorganização interna das aldeias, o que, segundo a autora, agravou-se com a morte da xamã. Cicarone dá ênfase à compreensão do caminho xamânico como a vivência cotidiana do drama que anuncia a iminência da destruição do mundo, inerente à mitologia Guarani. Este necessita ser sempre superado, sendo os Guarani os principais responsáveis por evitar a ocorrência do fim do mundo. Montardo (2002) registra a crença de que, para os Guarani, existe vida na Terra, porque eles a estão cuidando, e de que este cuidar passa pela tríade: cantar, rezar e dançar. Valdecir, liderança Guarani, em conversa comigo, revelou sua insatisfação pelo fato de os Guarani estarem do jeito que estão: "não era para os Guaranis estarem assim, destruídos", tendo em vista que eles são considerados os verdadeiros guardiões da Vida. Este pensamento, recorrente entre os Guarani, é interpretado por Pierre

\footnotetext{
7 Assuntos que envolvem o sistema religioso são muito bem guardados entre os Guarani do Rio Grande do Sul. Só comecei a ter acesso a conversas desta ordem, depois de um ano de pesquisa. Minha pesquisa foi realizada nas aldeias do Canta Galo (RS) com os Chiripá,Lomba do Pinheiro (RS) e Riozinho (RS) com os Mbyá e na aldeia de M'biguaçu (SC) com os Chiripá. Atualmente estou pesquisando com os Mbyá- Guarani na aldeia da Estrela Velha. Um dos motivos pelos quais estes assuntos são mantidos em segredo é a busca da preservação e também de um sentimento de medo que Nhanderú não goste que estas informações sejam divulgadas aos juruá, termo designado aos não indígenas.
}

Espaço Ameríndio, Porto Alegre, v. 2, n. 1, p. 111-128, jan./jun. 2008. 
Clastres (1990) como uma arqueologia do mal, uma incompletude por não atingirem o estado de perfeição, de saúde, de leveza, de divinização - aguyjé. Tal condição é necessária para que exerçam com dignidade a função de serem dançadores da Vida. Valdecir comentou sobre as palavras da Kunhã Karai ${ }^{8}$, sobre a importância de cada um cuidar de si e de sua família. O cuidar de si está ligado à internalização do que Pierre Clastres (1990) define como norma, ou rekoá para os Guarani: a moderação, a paciência e a calma, dentro de uma capacidade de guardar em si as regras da Vida.

Hélene Clastres (1978) faz uma discussão esclarecedora sobre o sentido do xamanismo entre os Guarani, o qual possui um aspecto religioso orientador. A partir dos relatos escritos feitos por Nimuendaju, declara a existência de uma hierarquia xamânica Guarani, que os divide em categorias de maior e menor expansão. A primeira, considerada negativa, é aquela em que se enquadram jovens e alguns adultos que ainda não receberam nenhum cântico e que, por isso, não podem dirigir as danças. A segunda é a dos homens e mulheres que já receberam uma inspiração, denotando a presença de espíritos auxiliares. Alguns deles podem dirigir as danças, mas não exercem poderes em nível coletivo. A terceira categoria abrange os xamãs capazes de curar, de prever e de batizar, e a quarta abarca os homens de grandes poderes, para além da comunidade, e que dirigem a dança do Nemongaraí, cerimônia destinada à proteção de animais, pessoas e plantas, também chamada Festa do Milho. Esses xamãs de grandes poderes são recordados pelos Guarani, como grandes Karaí dentro de um passado, de uma memória recente ligada ao pai ou avô que tem a função de comunicação espiritual. Os karaí são lideranças que dançam e cantam e lideram a sua aldeia.

Meliá (1991) refere-se à imagem circular das danças Guarani como uma expressão da participação, da união e da euforia de estar junto. Menezes (2006) descreve relatos orais, coletados nas aldeias Guarani, nos quais a dança Guarani surge com a criação do mundo. Como exemplo, a fala de Seu Adolfo, velho Guarani, que destaca a dança como originária do mboraí, ou seja, do canto. A simbolização da origem da dança é que esta é divina, portanto surgiu a partir de Nhanderú.

A redefinição do real e do mitológico para os Guarani é complexa,

\footnotetext{
${ }^{8}$ Liderança feminina religiosa que se comunica com as divindades e possui poder de cura.
} 
ANA LUISA TEIXEIRA DE MENEZES - A dança e o xamanismo ...

dentro de uma realidade que não acolhe, que não conhece, que não dialoga com este tipo de construção do pensamento e que, por conta disso, invalida-o. No depoimento do Alberto, professor Guarani fica clara a presença das fronteiras que se estabelecem entre as culturas, em função de um desconhecimento mútuo.

Quando eu era criança, eu senti o conhecimento verdadeiro. Era Guarani, não conhecia outro sentimento. Quando sai da aldeia, é como se fosse um vagabundo, um forasteiro. Ninguém sabia se eu era Guarani. Passava pela estrada, ninguém dava importância. Viajei para o inferno, depois voltei. Quando fui para minha terra, encontrei meu valor (ALBERTO, maio de 2005).

Os Karaí são os responsáveis por fazer as perguntas sobre a origem do universo, as mesmas que embasam as criações dos mitos e das teorias científicas. A complexidade das informações e as contradições trazidas pela realidade levam os jovens Guarani a indagarse sobre o futuro e sobre o passado, e reelaborar a história. É comum encontrar algum jovem declarando estar pesquisando as estórias com os mais velhos.

Hyral, neto de Seu Alcindo, é o jovem Cacique de M'biguaçú. Diz que o "Karaí é tudo, é a fonte de energia, é médico, psicólogo, pai, avô". Em uma de minhas visitas àquela aldeia, presenciei um certo momento em que a comunidade estava precisando fazer uma cerimônia para uma mulher que estava muito mal. O Hyral foi e participou como apoiador de Seu Alcindo. Mais tarde, ele comentou: "eu vou para dar força ao vô". Este diz que: "é muito difícil acreditar em tudo, ficar escutando cantos que não se entende". Reconhece as coisas boas que já recebeu e, ainda assim, duvida: "Eu tenho resposta para tudo, mas sou incrédulo". Hyral é um dos jovens que, ao questionar, alimenta sua própria curiosidade do saber. Sua fala é instigante e envolvente, do jovem que se movimenta pela dúvida, com dedicação e paixão. Ele consegue, em sua fala, fazer com que nós nos apaixonemos por aquilo que ele diz duvidar: sua cultura. É esta dúvida que produz o movimento dos jovens, e é no caminhar que essas indagações vão sendo feitas. É no caminhar que os mitos vão ganhando ou perdendo seu sentido, aquilo que Alberto diz sobre o conhecimento vivo, que os mantêm em um contínuo exercício 
de pensamento-percepção, fazendo-os seres de reflexão. O jovem Guarani é um pesquisador-dançarino de sua própria existência, ora negando, ora afirmando, ora se distanciando, ora defendendo, ora silenciando.

A vergonha é um sentimento que aparece como condição desta negação, evidenciando o caráter fenomenológico das vivências. Marcos, professor Guarani é um jovem que está fazendo um caminho de pesquisador que pesquisa a si mesmo. Fala que:

Quando eu tinha uns catorze anos, eu percebia outros
colegas meus que já não valorizavam mais a cultura e
pararam de estudar, saíram fora da aldeia, enfim,
esqueceram de seu povo. E isso eu vi com muitos
colegas meus. E depois, quando eu estudava fora, eu
sentia vergonha, eu sentia vergonha diante das
pessoas [...]. Às vezes, eu entrava dentro da sala de
aula e eu não era acostumado a botar camisa. Eu tinha
que botar camisa e eu botava, eu sentia vergonha. E
agora eu não sinto mais (MARCOS, julho de 2005).

O ato de conhecer, dentro da concepção xamânica Guarani, passa pelo percurso do auto-conhecimento; na verdade, não se separam. Nunes (2004) caracteriza o "conhecimento-emancipação" como aquele que consegue dialogar considerando os diversos modos de conhecimento e a experiência, sem usar a desqualificação mútua. Para o autor, todo conhecimento é auto-conhecimento, e destaca que, dentro deste lugar, o uso do corpo é um mediador na apreensão deste conhecimento. Corpo nu, corpo vestido, vergonha, emoção, alegria, tristeza, alma, são categorias relevantes na construção do caminhoconhecimento Guarani. Marcos conta como foi sua separação com a cultura, através de seus sentimentos:

Olha, eu não entrava antes [na $\left.O p y^{9}\right]$, mas pequeno eu entrava, quando eu era colo de mãe. Mas depois dos seis anos até os nove, eu comecei a deixar minha cultura de lado, porque eu estudava fora. E, quando eu entrei neste outro lado da cultura, eu achava que aquilo lá era mais importante do que a minha cultura e chegava em casa, não participava das cerimônias, enfim [...]. Onde que, mais tarde, já estava me sentindo [...] não estava me sentindo bem, eu estava triste. Eu

\footnotetext{
${ }^{9}$ Casa religiosa Guarani onde os rituais acontecem.
} 
ANA LUISA TEIXEIRA DE MENEZES - A dança e o xamanismo ...

estava na minha casa, olhava as pessoas, os meus parentes e não tinha sentido. A alegria que eu sentia antes, eu não sentia mais... (MARCOS, julho de 2005).

A afetividade é desenvolvida no presente estudo como uma categoria do conhecimento Guarani. Segundo Sawaia (1999), a afetividade define-se pelo sentimento: reações moderadas de prazer e desprazer que não se referem a objetos específicos e emoção definida enquanto um fenômeno ativo intenso que se centra nas circunstâncias e modifica o fluxo das condutas. Toro (2002) define afetividade como a capacidade que o ser humano tem de afinidade com outros seres vivos e que inclui sentimentos de ternura e de raiva, amor e ódio. Para o autor, os sentimentos têm duração no tempo. As emoções funcionam como elementos qualitativos da afetividade. Seguindo a perspectiva destes dois autores, analiso que emoções e sentimentos são mediadores na construção do conhecimento. Montardo (2002) revela que os Guarani, em suas práticas rituais de canto e dança, buscam o fortalecimento dos corpos, pela força e alegria, combatendo a tristeza e a raiva, se preparando para a vida. No estudo sobre a música Guarani, relata que a experiência de contato com a divindade é realizada através do corpo, o qual vai se transformando, de pesado e agressivo, para alegre e saudável. A idéia nos cantos e nas danças é que essa emoção se transforme em sentimento, que tenha duração no tempo, condição para se conseguir o aguyjé. Valdecir, liderança fala que, quando o Guarani dança, tem uma sensação de paraíso, uma vivência de estar num outro lugar ou estado, e que essa sensação de paraíso pode ser prolongada, ainda que essa capacidade seja sempre testada no cotidiano. Muitas vezes, segundo ele, quando se está nesse estado, algo de ruim acontece para você sair. Por exemplo, uma briga com a esposa. Aí acaba tudo. A idéia é que o estado de paraíso se prolongue na Terra. O sentimento de paraíso advindo da dança foi-me muitas vezes traduzido por "alegria". Marcos, em seu reencontro com a cultura, expressa bem o significado do termo "alegria" junto à noção de ensinamento e conhecimento.

Eu senti muita emoção, sim, emoção assim, não doer fisicamente, mas assim, espiritualmente. Porque antes eu sentia muita tristeza, não sabia o que fazer. Parece 
ANA LUISA TEIXEIRA DE MENEZES - A dança e o xamanismo ...

que estava aqui na Terra, mas não fazia sentido. Então foi aí que eu procurei a Opy, porque eu achava uma coisa importante deixar minha cultura de lado e foi aí que a minha alma estava me deixando, estava indo e foi aí que eu procurei a Opy, que eu entrei, comecei a cantar e foi aí que eu senti a primeira emoção, eu chorei, chorei para Deus mesmo e foi aí que até hoje [...]. Foi bem, se eu não tivesse procurado a $O p y$, eu não estaria vivo hoje, porque hoje eu acho que é importante a religião nossa e eu me senti mais alegre, eu comecei a abraçar as pessoas, né? Conversava com as pessoas e brincava, depois que eu saí da Opy. E até hoje eu continuo indo e eu achei que eu estava deixando minha cultura de lado. Então eu acho que hoje é importante o canto e a dança Guarani. Foi aonde eu aprendi e até hoje continuo (MARCOS, julho de 2005).

Os relatos dos Guarani sobre a dança retratam uma consonância com a função do rito, explicitada por Durkheim (1978), segundo o qual este auxilia-nos a viver, fazendo-nos agir, despertando-nos as forças emotivas que estão em nós, dentro de um plano mais transcendental, no qual a ação do rito e a repetição dos movimentos levam a uma cooperação ativa. Outro aspecto destacado pelo autor é a capacidade de idealização, de uma aprendizagem voltada para a imaginação, para as nossas aspirações mais belas e ideáticas.

Pierre Clastres (1990) refere-se ao processo de humanização como um processo coletivo e que não depende de uma relação individual de cada ser humano com seu Deus. A socialização e a própria individualização dão-se no processo de pertencimento à comunidade. Enquanto a pessoa possui uma caracterização do humano, de um corpo habitado, denominado de ñeë, o social é a afirmação da divindade, de onde a pessoa veio e para onde irá. A ética é coletiva, é a da divindade, do aguyjé, traduzido por Cadogán (1959) por perfeição, bem aventurança, que se revela na constituição tribal. Inácio, ao responder minha pergunta sobre a diferença de cada pessoa, referente à dança que cada um fazia, respondeu-me que "as pessoas são diferentes, mas o sentimento é tudo igual". Pierre Clastres (1990) refere-se a esse "nós" como solidariedade tribal - mborayu - e adverte-nos que esta solidariedade não se dá na perspectiva católica, sendo, entretanto, religiosa.

Espaço Ameríndio, Porto Alegre, v. 2, n. 1, p. 111-128, jan./jun. 2008. 
Segundo Hélene Clastres (1978), os ritos possuem uma origem religiosa, através da qual os sentimentos são subjetivados. A religião, por sua vez, sistematiza a idealização, característica própria do ser humano, produzindo assim uma socialização que dá fundamento à estrutura coletiva, na qual a fé é calor, vida, entusiasmo, uma passagem do indivíduo que transcende a si mesmo. A fé nutre-se deste compartilhar, da própria vida, das representações sensíveis que estão em fluxo permanente.

Rito e mito potencializam-se dentro da educação Guarani, em um movimento no qual o ideal e o real refazem-se e se pertencem continuamente dentro de uma estrutura religiosa refinada. Desta forma, emerge a individualização. O mito é uma matriz social e o rito é a ação corporal que transporta o ser humano para o mais elevado de sua existência. Conforme Campbell (1990), o rito desperta no ser humano o que há de melhor e não o que há de mais baixo de nossa natureza. Nesse sentido, o rito reeduca, através do movimento corporal e das emoções. Estas são vividas individualmente num espaço de expansão coletiva.

Conforme Balandier (1997), o mito aproxima dois mundos: revela o oculto e transmite parte da verdade, expressando um saber coletivo inato. Este saber é reforçado por imagens de forte carga afetiva. A dança, enquanto movimento ritualístico, representa um ato pessoal dentro de um corpo social e produz a conversão da esperança em ação. Para Campbell (1990, p. 86), "o ritual é o cumprimento de um mito. Ao participar de um ritual, você participa de um mito". O rito e o mito devem ser mantidos vivos, lançando-nos para um outro lugar, para fora e não para o cotidiano. O rito da dança-reza-canto vivifica o mito e transforma-se em uma vivência pessoal, portanto de autoconhecimento e de reconhecimento de um conhecimento comum.

O rito recria o conhecido e, assim, renova a tradição: aquilo que se deve repetir todos os anos como conhecimento, para ser consagrado como valor comum. Renova um saber cuja força é ser o mesmo para ser aceito. Repetir-se até vir a ser, mais do que apenas um saber sobre o sagrado, um saber socialmente consagrado (BRANDÃO, 1983, p. 35). 
ANA LUISA TEIXEIRA DE MENEZES - A dança e o xamanismo ...

Se, por um lado, o rito possui o aspecto ordenador, por outro, conforme acentua Escobar (1993), possui também uma função provocatica e desestabilizadora, pois possui uma qualidade trans-social, um espaço de formação do instante vivido:

[...] el rito impide que el contorno de lo social encastre consigo mismo y mantiene vivos lo ritmos desiguales del tempo coletivo; sin proponérselo, evita que el orden osifique las instituiciones y que el equilibrio paralice el curso trashumante del deseo o el vaivén permanente de las tensiones; para el rito, el drama nunca termina" (ESCOBAR, 1993, p. 195).

A desordem é desenvolvida na perspectiva de Balandier (1997), ou seja, como um alimento para a busca da ordem. A desordem que é vivida de uma forma singular dentro da comunidade Guarani, em sua própria estrutura mitológica, provoca o ato da dança. É no movimento que o Guarani encontra Nhanderú. A dança-rito coloca o corpo e o espírito em movimento num espaço de não rigidez, dentro de uma indissociável relação entre drama e sagrado.

Escobar (1993, p. 195) expressa muito bem o sentido do rito, "inventa ordens infinitas que duram um instante". É o que Cirilo, cacique na Lomba do Pinheiro, comenta sobre o estado das pessoas quando dançam: "Quando as pessoas dançam, não pensam em coisas más, não têm pensamentos ruins, se divertem e se alegram juntas. No verão é um outro mundo, uma outra vida". O verão é representado como o tempo em que se dança, o que não significa que todos os instantes do verão são de alegria. Esse instante também pode ser pensado como uma eternidade. É o que Daniel, um jovem Guarani que estava de passagem na Lomba do Pinheiro, falou quando olhou para a Opy, "quando eu olho para essa casa, sinto que parece que não vou sair mais daqui, é a casa do nosso Deus". Conforme Balandier (1997), o rito faz as dificuldades desaparecerem. Por um tempo, converte a incerteza em certeza.

Desta forma, podemos entender a educação Guarani como uma ação coletiva de intensa reinvenção, de uma tradição pouco monótona, dramatizada continuamente e que vive o rito, assumindo-o como permanência e mudança, dentro de uma pedagogia do movimento.

A palavra é também um importante instrumento no rito Guarani. 
Valdecir relata que o dançarino, o xondaro, não precisa de muito tempo de dança para ficar com a sensação de paraíso e que pode-se chegar a este estado mesmo sem dançar, só ouvindo a palavra. Esta palavra é falada ao ritmo do tambor, da rabeca, do violão, do mbarakálo, do pethenguá, do fogo e da escuridão. São sons e temperatura que propiciam ao corpo um estado de tônus mais sensível. As palavras chegam ao xondaro como uma mensagem divina e penetram num estado de consciência alterado.

Percebi uma semelhança do transe Guarani com o que Muller (1993) apresenta em seus estudos sobre a dança com os Assuriní do Xingu. A autora descreve a existência de dois tipos de transe, sendo que ambos fazem conexão com os espíritos. No primeiro, o xamã "morre" e se desloca para um outro mundo, tornando-se espírito e no segundo caso, o espírito animal assume o corpo humano, num processo de identificação mútua. A dança possui a função de atrair os espíritos, cumprindo uma função educativa-pedagógica.

O conhecimento válido é aquele que foi experimentado. Valdecir fala que existe o Karaí, que é vinculado ao $A r a n d u^{11}$ e existe a Kunhã Karaí, que, mesmo não tendo o Arandu, tem o poder de cura. Os dois são igualmente importantes. Segundo Adriano, professor de dança Guarani na aldeia do Canta Galo, Arandurekó é o conhecimento próprio, que se descobre dentro de si mesmo, sem ninguém dizer.

$O$ jovem busca ter acesso às experiências que possibilitam o êxtase, dentro de um sistema educativo que ordena suas próprias leis e que exige por parte das crianças, dos jovens, dos adultos e dos velhos um esforço diário de humanização, que implica no estar em paraíso na Terra. Santiago, liderança Guarani, disse-me uma vez que estava esperando um sinal para tornar-se Karaí. O mesmo acontece com o Seu José Verá que diz: "o Karaí não trabalha sozinho. Tem uma pessoa que cuida da porta para não entrar ninguém. Eu trabalho devagarinho. Nhanderú disse que eu sou novo ainda. Para o Karaí mesmo é a partir de 60 anos. Mas eu vou indo até lá". O Karaí vive dentro de um sistema xamânico, necessita da comunidade, da família, da mata, das crenças que têm o poder de intensificar o caminho ao êxtase. O Karaí é a pessoa

\footnotetext{
${ }^{10}$ Chocalho, instrumento musical rítmico.

${ }^{11}$ Ara é o que faz todos os dias e $n d u$ é o tempo de aprendizagem. Conhecimento que se aprende ao longo do tempo
}

Espaço Ameríndio, Porto Alegre, v. 2, n. 1, p. 111-128, jan./jun. 2008. 
ANA LUISA TEIXEIRA DE MENEZES - A dança e o xamanismo ...

fundadora a quem se refere Balandier (1997), através da qual o mito se organiza e se desenvolve.

O pensamento é uma qualidade do viver Guarani. Menezes (2006) ressalta em sua pesquisa a alta reflexividade dos jovens que estão sempre pensando sobre o sentido da vida e de seu caminhar. Bergamaschi (2005) fala de uma postura meditativa, refletindo que a cultura Guarani é caminhante, desde Nhanderú que vive dançando aos Guarani que vivem caminhando, tendo uma consciência que está sempre se dando a partir do movimento.

A dança, segundo Eduardo, professor na aldeia da Estrela Velha, traz pensamentos bons, mas ressalta que é somente dentro da Opy que os pensamentos se fortalecem, aparecem de uma forma diferente do que fora da Opy. Segundo Eduardo, "a Opy fortalece a língua e a cultura Guarani". Eduardo relata que "através da Opy as pessoas respeitam-se e reconhecem o que as pessoas são, mesmo que seja Guarani de fora da aldeia". Seguindo a visão de Gadamer apud Almeida (2007) "mítico significa o que guarda a verdadeira substância da vida de uma cultura" (p.3). Almeida (2007), a partir de Gadamer, pensa o mito a partir da linguagem. Para este autor, o mito faz lembrar que toda subjetividade pertence a uma substancialidade que a determina:

Os mitos são narrados e a narração exige a presença atenta do narrador e do ouvinte, somente nesse momento privilegiado de sua narração, o mito se efetiva. A circularidade que se constitui entre mito, narrador e ouvinte já denuncia a pertença a um "universo" comum. Aqui efetivação é atualização; a velha história, cuja origem remonta tempos esquecidos, se faz novamente atual e, como tal, não é mais velha história, mas é uma nova experiência, revitalizada em um novo tempo histórico e numa nova linguagem (ALMEIDA, 2007, p. 3).

A experiência da Opy lembra ao povo Guarani quem eles são, e o fazem, através da linguagem: do canto, da dança, das palavras antigas, que ao serem reconhecidas pelos jovens, se atualizam na vivificação do mito. Eduardo, diz que "eu mesmo não entendo as palavras dos antigos". O que significa este não entendimento? Gadamer (apud ALMEIDA, 2007) fala da distância mítica como uma característica do mito, ou seja, um apelo ao indeterminado, ao divino, é onde se estabelece a distância entre 
ANA LUISA TEIXEIRA DE MENEZES - A dança e o xamanismo ...

o que nomeamos e o que queremos nomear. O apelo ao divino é a nomeação divina de que só os deuses podem nomear e os Guarani como tradutores precisam estar permanentemente buscando diminuir esta distância através da narração. A narração é o canto, a dança e a palavra que nunca vai ser entendida completamente, pois assim acabaria a distância entre o divino e o terrenal, e o mito seria possuído. Para Gadamer (apud ALMEIDA, 2007), o mito não pode ser possuído, mas apenas narrado. O Karaí é o narrador, os Guarani são os ouvintes. Almeida (2007) destaca três aspectos na narração do mito: o narrador, o ouvinte e o narrado. O narrado é o que acontece na Opy. O autor descreve que a verdade do mito não está na autenticidade da narração, mas na experiência que ela provoca, nesse sentido não interessa muito se o Guarani vai entender todas as palavras, mas o que se desperta enquanto experiência com aquelas palavras. "O narrador é um ouvinte escolhido" (ALMEIDA, 2007, p. 6). O Karaí é aquele encarregado de passar a frente algo escutado em um momento anterior, e a experiência de ouvir é histórica, implica numa participação da comunidade. Nesse sentido, conforme nos apresenta Almeida (2007), o mito e a sua narração é um convite a tomar parte da história e a mostrar que não há história sem a sua participação. O mito une a comunidade, integra em torno de sua história, produz história e faz transcender a morte, circula entre a razão e a fé, entre os fatos e o mistério que não são dos deuses e de outras pessoas, são também das histórias da comunidade. Um exemplo desse pertencimento foi quando Eduardo narrou a experiência que viveu na $O p y$ onde viu quatro Guarani dançando, "depois de certo tempo ficaram deitados na Opy como se estivessem mortos". Contou que um deles se levantou e foi sentar num banco e assim ficou a noite toda, com muita dor no corpo. "Mas não era dor física, era dor interna, das coisas erradas que andavam fazendo". Relata que estes viveram uma espécie de morte e afirma que, ás vezes, é preciso morrer para vir um novo pensamento e conta que ficou apavorado com medo de dançar. Eduardo narra uma experiência sobre a morte de seu pai: "quando meu pai estava para morrer avisou a toda a nossa família - eu vou morrer hoje, bem calmo, desse jeito - meu pai gostaria que eu fosse junto. Eu fiquei quieto, não fiz nada". O mito atravessa a morte, permanece no indeterminado. 
ANA LUISA TEIXEIRA DE MENEZES - A dança e o xamanismo ...

O mito narra uma história que se constitui como um diálogo, sem interrupção e sem fim. Os tempos imemoriais de onde procedem as narrações míticas nos lembram que não há ruptura do diálogo já desde o passado; da mesma forma, a transposição da morte, através do culto aos mortos ou pelos mortos, afirma que, também no futuro, o diálogo deve continuar. O mito não suporta a irrupção do diálogo, por isso, o pensamento mítico dá "voz" aos que a morte já calou assim o diálogo continua e as respostas já não são dadas por alguém, mas pelo pensamento que se responde a si mesmo (GADAMER apud ALMEIDA, 2007, p. 9).

O mito, segundo o autor acima citado, continua dialogando no silêncio, sem interlocutores. Eduardo mesmo com o passar dos tempos, continua se indagando e dialogando, a respeito da morte de seu pai e de sua própria vida. O mito não morre e ele necessita despertar indagações, mistérios, diálogos, através dos quais o Guarani revive suas histórias e as recria.

\section{Referências bibliográficas}

ALMEIDA, Custódio Luís Silva de. O mito e o jogo como modelos originários para a vivência em Biodança. Texto elaborado para palestra no Seminário de Vivência em Biodança promovido pela Escola Gaúcha de Biodança. Porto Alegre, 2007.

BALANDIER, Georges. EI desorden: la teoria del caos e las ciencias sociales. Elogio de la fecundidad del movimiento. Barcelona: editorial Gedisa, 1997.

BERGAMASCHI, Maria Aparecida. Nhembo'e: Enquanto o encanto permanece! Processos e práticas de escolarização nas aldeias Guarani. 2005. 270 f. Tese (Doutorado em Educação) - Programa de Pós-Graduação em Educação, Universidade Federal do Rio Grande do Sul, [2005].

BRANDÃO, Carlos Rodrigues. Casa de Escola: cultura camponesa e educação rural. Campinas: Papirus, 1983.

BRUNELLI, Gilio. Do xamanismo aos xamãs: estratégias Tupi-Mondé frente à sociedade envolvente. In: LANGDON, Esther J. M. (Org.). Xamanismo no Brasil: novas perspectivas. Florianópolis: Editora da UFSC, 1996. p. 233-266. 
ANA LUISA TEIXEIRA DE MENEZES - A dança e o xamanismo ...

CADOGAN, León. Como interpretan los chiripá (avá Guarani) la danza ritual. Revista de Antropologia, São Paulo, v.7, n. 1 e 2, p. 65-99, jun./dez. 1959.

CAMPBELL, Joseph. O poder do mito com Bill Moyers. São Paulo: Palas Athena. 1990.

CHAMORRO, Graciela. Korusu Ne`Ëngatu: palabras que la história no podría olvidar. Asunción: Biblioteca Paraguaya de Antropologia, 1995.

CICARONE. Celeste. Drama e sensibilidade: migração, xamanismo e mulheres mbyá guarani. 2001. 296 f. Tese (Doutorado em Ciências Sociais) - Programa de Estudos de Pós-Gradução em Ciências Sociais, PUC-SP, [2001].

CLASTRES, Hélene. Terra sem mal: o profetismo tupi-guarani. São Paulo: Brasiliense, 1978.

CLASTRES, Pierre. A fala sagrada: mitos e cantos sagrados dos índios guaranis. Tradução de Nícia Adan Bonatti. Campinas: Papirus, 1990.

DURKHEIM, Émile. As formas elementares da vida religiosa. Tradução de Carlos Alberto Ribeiro de Moura. São Paulo: Abril Cultural, 1978.

ELIADE. Mircea. Mito do eterno retorno. Tradução de José A. Ceschin. São Paulo: Mercuryo, 1992. 1998.

O xamanismo e as técnicas arcaicas do êxtase. São Paulo: Martins Fontes,

ESCOBAR, Ticio. La Belleza de los otros: arte indígena del Paraguay. Asunción: Rediciones, 1993.

LANGDON, Esther Jean Matteson (Org.). Xamanismo no Brasil: novas perspectivas. Florianópolis: Editora da UFSC, 1996.

MELIÁ, Bartolomé. El guarani: experiencia religiosa. Asunción: Biblioteca Paraguaya de Antropologia, 1991.

MENEZES, Ana Luisa T. de. A Alegria do corpo-espírito saudável: ritos de aprendizagem Guarani. 2006. 256 f. Tese (Doutorado em Educação) - Programa de Pós-Graduação em Educação, Universidade Federal do Rio Grande do Sul, [2006].

MONTARDO, Deise L. O. Através do Mbaraka: música e xamanismo Guarani. 2002. 276 f. Tese (Doutorado em Antropologia Social) - Universidade de São Paulo, [2002]. Disponível em: http://www.teses.usp.br/teses/disponiveis/8/8134/tde-11032003-152546/ . Acesso em: 25 jun. 2008.

MÜLlER, Regina. P. Os Asuriní do XINGU: história e arte. Campinas: Editora da UNICAMP, 1993. 
NUNES, João Arriscado. Um discurso sobre as ciências 16 anos depois. IN: SANTOS, Boaventura. S. (Org.). Conhecimento prudente para uma vida decente. São Paulo: Cortez, 2004. p. 59-84.

RODRIGUEZ, José Ezequiel Basini. Estratégias econômicas, políticas e religiosas na mito-práxis Mbyá Guarani. 1999. 240 f. Dissertação (Mestrado em Antropologia Social) - PPGAS, UFRGS, [1999].

SAWAIA, Bader. B. O sofrimento ético-político como categoria de análise da dialética exclusão-inclusão. In: . As artimanhas da exclusão. Petrópolis: Vozes, 1999. p. 97-118.

TORO, Rolando Aranenda. Biodanza. São Paulo: Editora Olavobrás, 2002. 